\title{
Food waste in Central Europe - challenges and solutions
}

\author{
Jan den Boer ${ }^{1, *}$, Przemystaw Kobel $^{1}$, Arkadiusz Dyjakon ${ }^{1}$, Klaudia Urbańska ${ }^{1}$, Gudrun \\ Obersteiner $^{2}$, Marlies $\mathrm{Hrad}^{2}$, Elisabeth Schmied ${ }^{2}$, and Emilia den Boer $^{3}$

\begin{abstract}
${ }^{1}$ Wroclaw University of Environmental and Life Sciences, Institute of Agricultural Engineering, ul. Chelmonskiego 37a, 51-630 Wroclaw, Poland

${ }^{2}$ University of Natural Resources and Life Sciences, Department of Water, Atmosphere and Environment, Institute of Waste Management, Muthgasse 107, 1190 Vienna, Austria

${ }^{3}$ Wrocław University of Science and Technology, Faculty of Environmental Engineering, Wybrzeże Wyspańskiego 27, 50-370 Wrocław, Poland
\end{abstract}

\begin{abstract}
Food waste is an important issue in the global economy. In the EU many activities aimed at this topic are carried out, however in Central Europe is still quite pristine. There is lack of reliable data on food waste quantities in this region, and not many preventive actions are taken. To improve this situation the STREFOWA (Strategies to Reduce and Manage Food Waste in Central Europe) was initiated. It is an international project (Austria, Czech Republic, Hungary, Italy, Poland), founded by the Interreg Central Europe programme, running from July 2016 to June 2019. Its main purpose is to provide solutions to prevent and manage food waste throughout the entire food supply chain. The results of STREFOWA will have positive economical, social and environmental impacts.
\end{abstract}

\section{Introduction}

Food is one of the largest existing product flows. It is often suggested, that up to half of all food grown is lost or wasted and thus not eaten [1]. Estimates on the global level of food wastage by the FAO state that 'roughly one-third of the edible parts of food produced for human consumption, gets lost or wasted globally, which is about 1.3 billion ton per year [2]. Parfitt presented results of an overview on food waste quantity studies, coming up with estimates for the post consumer food waste for the United Kingdom of $25 \%$, for the United States up to $15 \%$, for The Netherlands $8-11 \%$ and for Turkey $9 \%$ [3].

In Central Europe however, the available data on food waste generation is limited. In the frame of a recent 7th Framework European project, Fusions, an attempt was done to obtain data from EU Member States. The results for the Central European Member states are shown in table 1 below.

\footnotetext{
* Corresponding author: jan.denboer@upwr.edu.pl
} 
Table 1. Assessment of food waste data provided by Central European Member States within the Fusions project [4].

\begin{tabular}{|c|c|c|c|c|c|c|c|}
\hline Country & 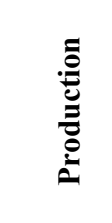 & 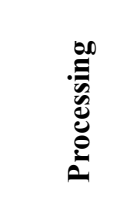 & 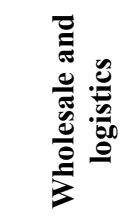 & 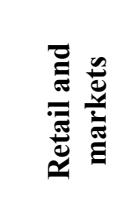 & 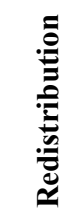 & 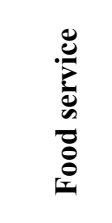 & $\begin{array}{l}\text { 픙 } \\
\frac{0}{0} \\
0 \\
0 \\
0\end{array}$ \\
\hline Bulgaria & no data & no data & no data & no data & $\begin{array}{c}\text { no } \\
\text { data }\end{array}$ & no data & no data \\
\hline Croatia & $\begin{array}{c}\text { low } \\
\text { quality }\end{array}$ & $\begin{array}{c}\text { low } \\
\text { quality }\end{array}$ & $\begin{array}{c}\text { low } \\
\text { quality }\end{array}$ & $\begin{array}{c}\text { low } \\
\text { quality }\end{array}$ & $\begin{array}{c}\text { no } \\
\text { data }\end{array}$ & $\begin{array}{c}\text { low } \\
\text { quality }\end{array}$ & $\begin{array}{c}\text { low } \\
\text { quality }\end{array}$ \\
\hline Czech republic & $\begin{array}{c}\text { low } \\
\text { quality }\end{array}$ & $\begin{array}{c}\text { low } \\
\text { quality }\end{array}$ & $\begin{array}{c}\text { low } \\
\text { quality }\end{array}$ & $\begin{array}{c}\text { low } \\
\text { quality }\end{array}$ & $\begin{array}{c}\text { no } \\
\text { data }\end{array}$ & $\begin{array}{c}\text { low } \\
\text { quality }\end{array}$ & $\begin{array}{c}\text { low } \\
\text { quality }\end{array}$ \\
\hline Estonia & no data & $\begin{array}{c}\text { low } \\
\text { quality }\end{array}$ & $\begin{array}{c}\text { sufficient } \\
\text { quality }\end{array}$ & $\begin{array}{c}\text { sufficient } \\
\text { quality }\end{array}$ & $\begin{array}{c}\text { no } \\
\text { data }\end{array}$ & $\begin{array}{c}\text { low } \\
\text { quality }\end{array}$ & $\begin{array}{c}\text { sufficient } \\
\text { quality }\end{array}$ \\
\hline Hungary & no data & no data & no data & no data & $\begin{array}{c}\text { no } \\
\text { data }\end{array}$ & no data & no data \\
\hline Latvia & no data & no data & no data & no data & $\begin{array}{c}\text { no } \\
\text { data }\end{array}$ & no data & no data \\
\hline Lithuania & $\begin{array}{c}\text { low } \\
\text { quality }\end{array}$ & $\begin{array}{c}\text { sufficient } \\
\text { quality }\end{array}$ & $\begin{array}{c}\text { low } \\
\text { quality }\end{array}$ & $\begin{array}{c}\text { low } \\
\text { quality }\end{array}$ & $\begin{array}{c}\text { no } \\
\text { data }\end{array}$ & $\begin{array}{c}\text { low } \\
\text { quality }\end{array}$ & $\begin{array}{c}\text { low } \\
\text { quality }\end{array}$ \\
\hline Poland & no data & no data & no data & no data & $\begin{array}{c}\text { no } \\
\text { data }\end{array}$ & no data & no data \\
\hline Romania & no data & no data & no data & no data & $\begin{array}{c}\text { no } \\
\text { data }\end{array}$ & no data & no data \\
\hline Slovakia & $\begin{array}{c}\text { low } \\
\text { quality }\end{array}$ & $\begin{array}{c}\text { low } \\
\text { quality }\end{array}$ & no data & no data & $\begin{array}{c}\text { no } \\
\text { data }\end{array}$ & no data & no data \\
\hline Slovenia & $\begin{array}{c}\text { low } \\
\text { quality }\end{array}$ & $\begin{array}{c}\text { low } \\
\text { quality }\end{array}$ & $\begin{array}{c}\text { sufficient } \\
\text { quality }\end{array}$ & $\begin{array}{c}\text { sufficient } \\
\text { quality }\end{array}$ & $\begin{array}{c}\text { no } \\
\text { data }\end{array}$ & $\begin{array}{c}\text { low } \\
\text { quality }\end{array}$ & $\begin{array}{c}\text { low } \\
\text { quality }\end{array}$ \\
\hline
\end{tabular}

In general the data on food waste generation in Central Europe is of low quality or is completely lacking. Exceptions are smaller countries, that have an over-average GDP, like Estonia and Slovenia. These countries provided with data that was partly of sufficient quality. However the larger countries, like Poland and Romania did not provide with any data. In figure 1 an overview is given on the food waste generation data availability in the European Union. 


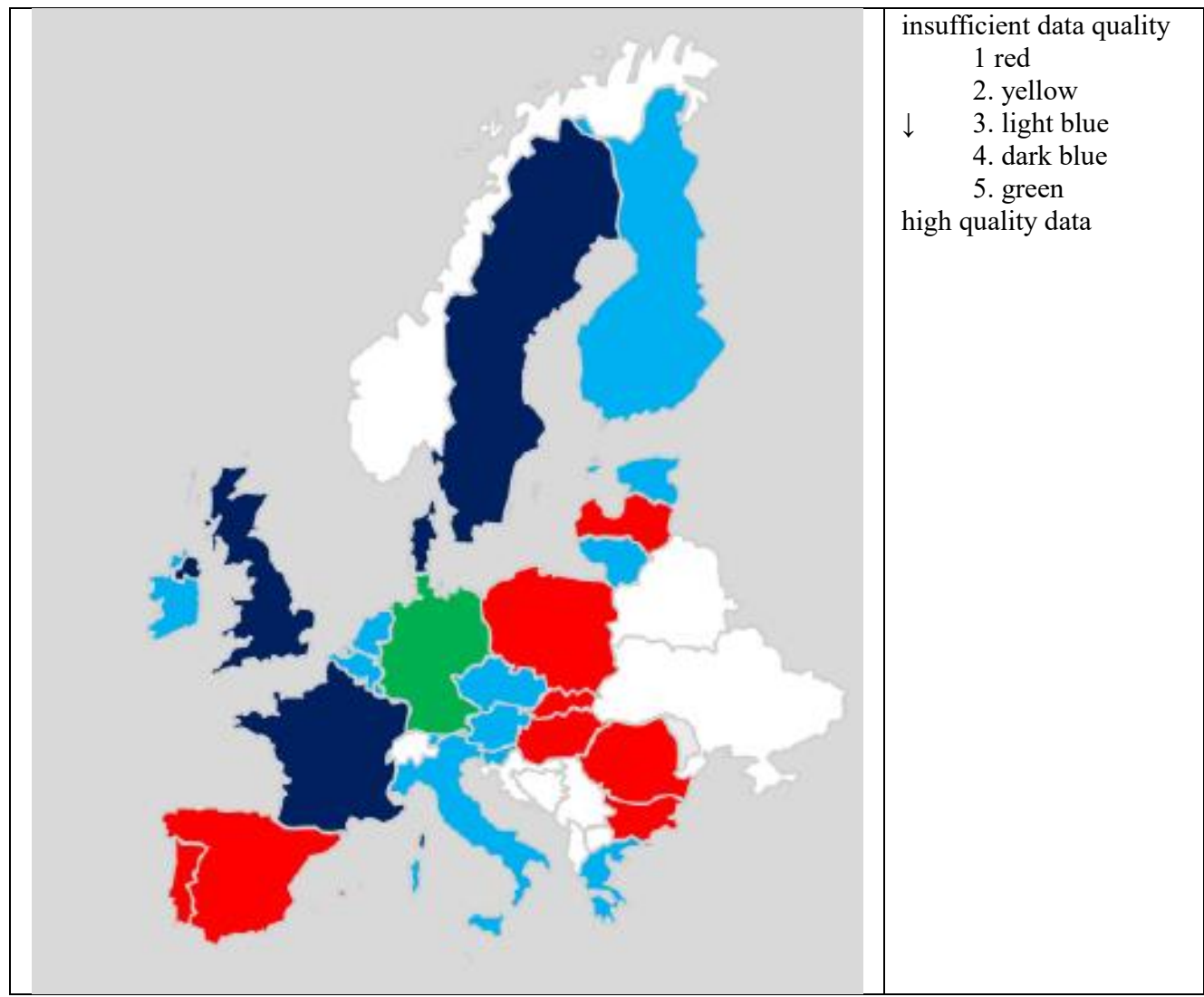

Fig. 1. Food waste data provided by Member States within the Fusions project [4].

The overall assessment of the food waste data quality as provided in figure 1 shows that the situation is far from positive for most Central European countries. However, based on generic indicators for food waste generation in specific sectors and the size of those sectors in the considered countries (e.g. number of inhabitants, number of hotel stays, number of meals prepared in restaurants and catering) estimated of the amounts of generated food waste can be made. BIO Intelligence Service came up with an European wide overview for several sectors in the year 2010, partly based on older (2006) data [5]. In table 2 the figures for the Central European Member States are provided.

Table 2. Estimates of food waste generation in Central European Member States (kg/inh.yr). Adjusted from [5].

\begin{tabular}{|c|c|c|c|c|}
\hline Country & 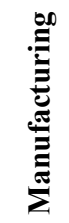 & $\begin{array}{l}0 \\
\frac{0}{0} \\
\frac{0}{0} \\
0 \\
0 \\
0\end{array}$ & 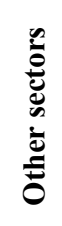 & $\begin{array}{l}\overline{\tilde{\sigma}} \\
\stackrel{\theta}{0}\end{array}$ \\
\hline Bulgaria & 49 & 39 & 4 & 91 \\
\hline Czech republic & 35 & 25 & 11 & 71 \\
\hline
\end{tabular}




\begin{tabular}{|c|c|c|c|c|}
\hline Country & 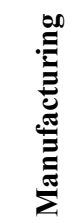 & $\begin{array}{l}n \\
\overline{0} \\
\overline{0} \\
0 \\
0 \\
0\end{array}$ & 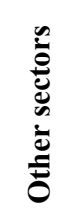 & $\stackrel{\bar{\sigma}}{0}$ \\
\hline Estonia & 179 & 62 & 27 & 268 \\
\hline Hungary & 116 & 40 & 31 & 186 \\
\hline Latvia & 55 & 35 & 5 & 95 \\
\hline Lithuania & 62 & 31 & 69 & 162 \\
\hline Poland & 170 & 53 & 9 & 233 \\
\hline Romania & 22 & 31 & 49 & 102 \\
\hline Slovakia & 64 & 25 & 19 & 108 \\
\hline Slovenia & 21 & 36 & 32 & 89 \\
\hline
\end{tabular}

Apart from the lack of precise data in Central Europe, the striving to solutions is as well focused mainly on Western and Northern Europe. This is both true for research and demonstration project funded by the European Commission (e.g. FUSIONS, Food Use for Social Innovation by Optimising Waste Prevention Strategies, FP7; REFRESH, Resource Efficient Food and dRink for Entire Supply cHain, Horizon2020; FORWARD, Food Recovery and Waste Reduction, Life Long Learning Programme), national research and demonstration programmes (e.g. in Austria, Germany, The Netherlands, Denmark, Sweden, the UK) and national and transnational activities of NGO's.

For the reasons mentioned above, the project STREFOWA was initiated. STREFOWA stands for 'Strategies to Reduce and Manage Food Waste in Central Europe'. It is funded within the Interreg Central Europe programme. Although in Central Europe the exact amounts and composition of generated food waste is rather unknown, the main focus of the project is not on retrieving reliable data. The acquiring of such data is a costly and time consuming process. Apart from the fact, that it is harder to find funding for food waste data research than for implementation of solutions, it is also obvious that the food waste problem also exists in Central Europe. Therefore the main focus of the STREFOWA project is to demonstrate new as well as existing solution to prevent and manage food waste in a Central European context.

\section{STREFOWA project: Background}

The project 'Strategies to Reduce and Manage Food Waste in Central Europe', STREFOWA, runs from July 2016 to June 2019. It is implemented in Austria, the Czech Republic, Hungary, Italy and Poland. 


\subsection{Goal and objectives}

The main goal of the STREFOWA project is to improve food waste management in selected Central European urban areas by fostering food waste prevention as well as proper treatment and therefore reduce greenhouse gas emissions.

This main goal can be divided into three objectives:

- To improve prevention of food waste in urban areas. By establishment of strategies to avoid food waste along whole value chain (agriculture commerce/gastronomy - households) through training programmes and awareness raising, stakeholder participation processes and cooperation strategies. These will be tested via different pilot actions;

- To improve treatment of food waste in urban areas. Definition of options to collect and treat food waste in sustainable way and introduction of new collection schemes and test facilities to separate organic from residual waste as well as introduction of new innovative treatment options for food waste;

- To improve knowledge on food waste management. All findings will end up in the interactive, tailored to different users (private persons, local authorities, restaurateur, retailers, teachers, waste management authorities...) web based decision support tool which will provide best practice guidelines, training material, guidelines etc. adjusted to all relevant public and private actors.

\subsection{Consortium}

Within the STREFOWA project a number of project partners with various geographical, cultural and expertise backgrounds is working together under the lead of the University of Natural Resources and Life Sciences, Vienna. The consortium consists of the following partners:

1. University of Natural Resources and Life Sciences, Vienna (ABF-BOKU, Austria)

2. Glopolis, p.s.c (Glopolis, Czech Republic)

3. Waste Management Association Mid-Tyrol (ATM, Austria)

4. Province of Rimini (Province of Rimini, Italy)

5. Langhe Monferrato Roero Development Agency (LAMORO, Italy)

6. Wrocław University of Environmental and Life Sciences (WUELS, Poland)

7. Bay Zoltán Nonprofit Ltd. for Applied Research (BZN, Hungary)

8. Federation of Polish Food Banks (FPFB, Poland)

9. Square Bracket eU (Square Bracket eU, Austria)

10. SPAR Hungary Ltd. (SPAR, Hungary)

Apart from the project partners, three institutions are associated to the project, not being a formal project partner: the Municipal Department 22 of the city of Vienna, the Municipality of Asti and Waste Treatment Ahrental Ltd.

\section{STREFOWA project: Approach}

\subsection{Intended project outputs}

The STREFOWA project aims to reach overall outputs in the area of transnational cooperation, tools, training \& education as well as demonstration. The intended project outputs that will be reached by the end of the project duration are: 
- Food Waste Prevention Tool. All relevant project outcomes will be included in an interactive web based tool providing information on food waste prevention and management tailored to different users (consumers, restaurateurs, retailers, authorities...) in English and localised language to partner countries. The Tool will include best practice guidelines along the food supply chain, training and education material, outcomes of the pilot activities and information on environmental benefits. The results of the Food Waste Hackathons that will be organised in the frame of the project also serve as input for the Tool.

- Pilot Actions on the reduction and management of food waste. Demonstration projects on food waste prevention will be performed. According to indentified deficits and existing best practice models proper approaches for food waste prevention will be implemented in various functional urban areas. The optimisation of biowaste (esp. food waste) collection will be tested for hotels. Separate collection biowaste collection will be introduced and tested in at least one functional urban area. The content of food waste in residual waste will be reduced via specific sorting aggregates.

- Guidelines and training on food waste prevention and management. For all sectors along the food chain guidelines and training programmes aiming at the prevention and management of food waste will be developed. Pilot trainings will be implemented and all materials will be compiled in a Handbook on food prevention and treatment approaches

- Action plan on long-term transnational umbrella organisation on food waste. An association will be formed existing of a conglomerate of food waste prevention and management experts that will cooperate beyond the time frame of the project on newly developing themes in the field.

\subsection{Pilot Actions}

An important mean to reach the project objectives is the implementation of pilot activities. In functional urban areas located in the project partner's countries it will be demonstrated, that approaches and methods for the prevention, collection and treatment of food waste will lead to positive results in the designated cities. These measures have been used in other geographic regions already and were identified as 'best practices'.

In table 3 an overview of the intended Pilot Actions is given.

Table 3. Planned Pilot Actions in the STREFOWA project.

\begin{tabular}{|c|c|c|}
\hline Pilot Action & Description & Urban functional area \\
\hline Food waste prevention & redistribution & Vienna \\
\hline $\begin{array}{c}\text { agriculture and food } \\
\text { industry }\end{array}$ & reuse, donation to foodbanks & $\begin{array}{c}\text { Warsaw, Prague, Asti, } \\
\text { Hungary }\end{array}$ \\
\hline retail & $\begin{array}{c}\text { hotels and restaunts: donation and } \\
\text { prevention }\end{array}$ & Vienna, Rimini \\
\hline gastronomy & $\begin{array}{c}\text { educationseholds } \\
\text { houencing }\end{array}$ & Vienna, Prague, Asti \\
\hline schools & raising awareness in households & Vienna, Rimini \\
\hline consumers & & \\
\hline Food waste collection & & \\
\hline
\end{tabular}




\begin{tabular}{|c|c|c|}
\hline Pilot Action & Description & Urban functional area \\
\hline gastronomy & $\begin{array}{c}\text { optimisation of separate collection of } \\
\text { food waste in hotels }\end{array}$ & Rimini \\
\hline households & $\begin{array}{c}\text { introduction of separate collection of } \\
\text { biowaste from consumers }\end{array}$ & Wroctaw \\
\hline Food waste treatment & & Innsbruck \\
\hline $\begin{array}{c}\text { Sorting out of food } \\
\text { waste from residual } \\
\text { waste }\end{array}$ & $\begin{array}{c}\text { additional sorting aggregate in an } \\
\text { existing mechanical-biological } \\
\text { pretreatment plant. The organic } \\
\text { fraction will be digested } \\
\text { anaerobically. }\end{array}$ & \\
\hline
\end{tabular}

The outcomes of the pilot actions will be assessed both on their economic effectiveness (how much efforts it costs to come to the results) and their environmental impacts. For the environmental impacts a Life Cycle Assessment approach will be used, resulting in the amounts of avoided Greenhouse Gas emissions for each Pilot Action.

\section{Conclusions}

In today's world of declining natural resources and increasing environmental degradation, reducing the amount of lost or wasted food is one of the most important priorities.

In the EU a variety of programs and activities on this important topic is carried out at the international, national and local level. STREFOWA is in line with this pan-European trend but focuses its efforts on the relatively pristine area of Central Europe.

Its main purpose is to provide solutions to prevent and manage food waste. Project activities focus on all aspects of the food supply chain. The project results are intended to be used by professionals within the food supply chain (e.g. farmers, retailers, restaurateurs), authorities (regional, municipal, etc.), NGOs and the general public.

Implementation of the project will cause following positive effects:

- $\quad$ the improvement of resource efficiency (to avoid food loss);

- the improvement of the social situation (donation of excess food to feed the needy);

- the improvement of energy efficiency (use of food waste for energy production);

- the prevention of climate change (reduction of greenhouse gases emissions).

\section{Acknowledgements}

This paper emerged in the frame of the project STREFOWA 'Strategies to Reduce and Manage Food Waste in Central Europe', which is co-financed by the Interreg CENTRAL EUROPE Programme that encourages cooperation on shared challenges in central Europe. With 246 million Euro of funding from the European Regional Development Fund, the programme supports institutions to work together beyond borders to improve cities and regions in Austria, Croatia, Czech Republic, Germany, Hungary, Italy, Poland, Slovakia and Slovenia. 


\section{References}

1. J. Lundqvist, C. de Fraiture, D. Molden, Saving water: from field to fork-curbing losses and wastage in the food chain. In SIWI Policy Brief. Stockholm, Sweden: SIWI (2008)

2. FAO. Global food losses and food waste - Extent, causes and prevention, Rome (2011)

3. J. Parfitt, M. Barthel, S. Macnaughton, Phil. Trans. R. Soc. 365 (2010)

4. Å. Stenmarck, C. Jensen, T. Quested, G. Moates, Estimates of European food waste levels. ISBN 978-91-88319-01-2. Stockholm (2016)

5. BIO Intelligence Service. Preparatory Study on Food Waste Across EU27, final report-2010-54 for the European Commission (DG ENV) Directorate C - Industry, ISBN: 978-92-79-22138-5. BIO Intelligence Service in association with Umweltbundesamt and AEA (2010)

6. BIO Intelligence Service. Assessment of resource efficiency in the food cycle, Final report prepared for European Commission (DG ENV) in collaboration with AEA, Dr Donal Murphy-Bokern, Institute of Social Ecology Vienna and Institute for Environmental Studies (2012) 